\title{
The Logic of Party Government: A Comparative Perspective
}

by Jan-Erik Lane

\begin{abstract}
Democracy in Europe takes the form of party government. This paper suggests a quantitative method for analysing power under party government comparatively. Looking upon political parties as coalitions among the parliamentarians, both the power of the party and the power of individual parliamentarians may be estimated. Two kinds of coalitions are essential: internal and external ones. Based on an analysis of the Nordic countries, the findings include, first, large deviations - positive and negative - from strict proportionality between party mandates and power over time (the holistic perspective), as well as, second, individual rationality among parliamentarians (the individualistic perspective).

Demokratie in Europa findet sich vor allem in der Form von Parteienregierungen. Dieser Artikel schlägt eine quantitative Methode vor, um Macht in Parteienregierungen vergleichend zu analysieren. Betrachtet man politische Parteien als Koalitionen zwischen Parlamentariern, so kann sowohl die Macht der Partei als auch die Macht des einzelnen Abgeordneten eingeschätzt werden. Zwei Arten von Koalitionen sind dabei relevant: interne und externe. Die auf einer Untersuchung der nordischen Staaten beruhenden Ergebnisse verweisen einerseits auf große - positive und negative - Abweichungen von einer strikten Proportionalität zwischen Parteimandaten und der Macht im Zeitablauf (holistische Perspektive), andererseits auf die individuelle Rationalität einzelner Parlamentarier (individuelle Perspektive).
\end{abstract}

\section{Introduction}

In European democracies, political power is vested firmly in the hands of the political parties. Even when charismatic personalities shake up the party landscape, they move quickly to create new political parties as the instrument of exercising power through elections, parliamentary voting and government formation. In Western Europe, one finds the highly disciplined political party that rarely accepts that some of its politicians vote against the party line in the national assembly. To become Premier or President always requires the backing of the political party.

I am grateful to Reinert Maeland who made all the calculations used in this article. He is not responsible for the argument presented. 
A political party is essentially a set of politicians who gather together to coordinate their behaviour in order to contest elections and to win mandates for the national assembly. This group of people hires staff in order to run their organisation, i.e. the political party emerges with its hierarchical structure, geographical coverage and links to support groups. A variety of conceptual frameworks has been launched to model what is characteristic of political parties: from the iron law of oligarchy (Michels), the catch-all party (Kirchheimer) against the electoral niche party (Rokkan), the cartel party (Mair) to the most recent principal-agent approach (Lane). ${ }^{1}$ Here, we will focus upon power, more specifically the voting power different parties may exercise in the national assembly, as the party access to valuable resources depends upon its parliamentary power, whether the party aims at promoting internal or external objectives.

Political power is an essentially contested notion. Among the various definitions of "power" available in the literature, the so-called power index offers certain advantages (power as decisiveness - cf. Appendix), especially if one concentrates upon power in the representative assembly and looks for a quantitative measure that could be reproduced for different countries, time periods and various kinds of parties. In this article, we will show how the capacity of political parties to exercise voting power in the national assembly can be analysed comparatively, over both time and space. We look at Nordic democracy from the Second World War to the present situation after the most recent elections.

\section{The Party and Its Parliamentarians}

A political party is ontologically speaking a group of people who join forces in order to increase their political clout. Thus, a political party is a more or less permanent so-called $n$-person coalition, in the terminology of cooperative game theory. Speaking of political parties as if they were autonomous or holistic actors, one easily falls into the trap of reification, i.e. the fallacy of misplaced concreteness. Political parties are not independent units or social systems, but merely what the coalition of people who enter into them turns them into, especially its group of parliamentarians or representatives in the national assembly..

Whatever motives drive people to gather into political parties, one basic rationale is voting power, especially in a parliamentary democracy. By combining with others, people create groups strong enough to contest elections, win mandates in 
the representative assembly and form government coalitions. Voting power is a most important means for promoting the incentives of parliamentarians, whether their objectives be pecuniary or non-pecuniary, self-centred or oriented towards their supporters/voters.

In our approach, political parties may be interpreted as coalitions in two meanings. First, they are made up of internal coalitions among politicians with a more or less similar political vision, offering their services as agents of the principal of the body politic, i.e. the demos. Second, they enter into external coalitions with other parties with a different political vision. Both these kinds of coalitions internal and external - may crumble, when some people leave a party group or parties break loose from a governing coalition. In our approach, one may calculate two power measures, one for the party as such and another for the politician constituting the party - here its parliamentarians. We will raise two questions stemming from this approach:

- Power of the party: Which political parties are successful over time, meaning that they score a power measure that is larger than their percentage of representation? A party scoring considerably more power than its share of representation would qualify as a hegemonic party, whereas a party that on average score much lower than its share of political representation would be evolutionarily unfit.

- Power of the parliamentarians: Parliament takes a huge number of decisions during a specified interval of time. It is true that under party government the actors in these collective decisions are the political parties that tend to vote with one voice, based on their differential number of mandates. But one may ask whether parliamentarians manage to attain a degree of power that is larger than what they could accomplish by voting as autonomous members of the assembly.

\section{Stresemann's Latchkey to Power: The Coalitions}

This article explores the logic of party government in representative democracies with a parliamentary regime, suggesting a new and refined method for estimating the power of political parties and their individual parliamentarians, given a high degree of party discipline.

No one tried harder to master this logic than Gustav Stresemann, wielding power in the Weimar Republic from 1923 to 1929 . He saw correctly the latchkey to power in party government in coalitions among parliamentarians. He had to make two kinds of coalitions on a continuous basis: (1) internal party coalition to 
keep his own party (DVP) together; (2) external coalitions with other parties to support either a minority or a majority coalition. ${ }^{2}$

Thus, one would wish to have a method of analysis that would allow for the illumination of a few much discussed hypotheses about parties and party representatives under the regime of party government. First, we have the classical Lipset-Rokkan hypotheses that the political parties receive much different support over time, as if the party system was frozen somehow. It entails that political parties will have different shares of the representation in the national assembly: does it result in a variation in political power for the parties over time? Is the power of a political party proportional to its representation in Parliament? Second, we have the hypotheses in coalition theory that rational players join coalitions that bring them at least as much power as they could achieve by themselves - the superadditivity hypotheses. Both these theories - the longitudinal hypothesis about a ratio between party representation and party power as well as the hypothesis about the individual parliamentarian coalition behaviour can be explored in all countries that institutionalise party government, such as, for instance the Nordic democracies adhering to multi-party parliamentarism or any European democracy with strong party discipline.

Here, we will examine data about voting power in the Nordic Parliaments over time as well as the present situation. To model voting in a national parliament, we will use cooperative game theory, or more specific, $n$-person games (cf. Appendix). Within these $n$-person games, we find the so-called simple games with two outcomes: win or lose. In a real parliamentary voting session, winning translates into an acceptance of the proposal voted upon, while losing accordingly entails a rejection of said proposal. Given a proposition (bill, amendment, budget item, etc), the players form either supporting or opposing coalitions. The total value the game, the payoff, is subsequently assigned to the winning coalition, while the losing coalition gets nothing. Since win or lose are the only outcomes of such voting games, we simplify the calculations by normalizing the payoff to 1 and 0 , hence the notion of a simple game. We calculate three voting power measures:

- Scores for single parliamentarians;

- Scores for the entire party before government formation;

- Scores for the whole party after government formation. 
Below we reproduce a few Tables for party government in Scandinavia as well as Finland and Iceland that cover both the main developments since 1945 and the present situation.

\section{Power of the Party over Time - 1945-2010 (Power/Seats)}

During the post-War period, Nordic Parliaments have used various proportional election methods have thrown up a multi-party system with a degree of fractionalisation hovering roughly around 5-8 parties. This necessitates the formation of coalition governments. Typical of Scandinavia has been the frequent occurrence of minority coalition governments. On the contrary, Finnish parliamentarism has been very different, leaning towards the employment of oversized coalitions, party due to the institutional requirement of $60 \%$ support for key decisions in Parliament. Finally, Iceland practices majoritarian democracy with coalition governments that are minimum winning and often minimum sized.

Political parties, when looked upon holistically as one player due to strong party discipline in Parliament, can accomplish power in two ways. It can participate in a coalition government and enjoy its share of the power of the government. Or it can act outside of a government, scoring voting power in the constantly ongoing voting in Parliament. In a year, there are thousands of such votes cast in relation to legislation, budgeting, taxation and general statements of policy. When there is a simple majority government, then this coalition receives 1 and the opposition 0 over all voting. And the gain of the government coalition is distributed onto the participating parties $n$ in accordance with the fomula $1 / n$, as each party is necessary to the government caliation, whatever the size of the party may be. When there is a minority coalition government, then it receives its Banzhaf player score just as the other parties, acting holistically as one player, due to party discipline. Thus, all parties score power when there is a minority government.

Table 1 reports upon the deviations between party mandates and power for the entire post-War period in all five countries for all the polical parties.

The finding is that minority coalitions enhance power-seat proportionality, as Denmark and Norway display small deviations on average. Matters are entirely different for Finland and Iceland where some parties have much higher "Koalitionsfähigkeit" than others. In Sweden, the average deviation of 4 per cent derives from the hegemonic position of its Social Democrats. This institutional effect - simple majority coalitions being conducive to power-seat disproportionalities even when the time span is a very long one - should be investigated for 
Table 1: Aggregated deviations from strict proportionality: power and mandates of parties 1945-2009

\begin{tabular}{c|c}
\hline Country & Power-Seats $\mid \mathbf{N}$ \\
\hline Denmark & 0,021 \\
\hline Norway & 0,021 \\
\hline Sweden & 0,035 \\
\hline Iceland & 0,054 \\
\hline Finland & 0,058 \\
\hline
\end{tabular}

Note: These scores are based upon normalised measures that first measure the absolute distance between the percentage of mandates for the parties and second the percentages of voting power for the parties on a country basis (normalised Banzhaf scores).

other political systems with party government, like the UK and Germany, both Weimar and the FRG.

Table 2 shows the political parties with the largest deviations from strict proportionality. This Table contains much of the political history of Nordic democracies during the after War period, where a few parties managed to reach some 710 per cent more power than what their share of the parliamentary mandates implied, accoding to strict proportionality between voting power and seats.

Table 2: Deviations from Strict Proprotionality (Power - Seats) 1945 - 2009

\begin{tabular}{l|c|c|c|c}
\hline Country & Party & $\begin{array}{c}\text { Power }- \\
\text { Seats }\end{array}$ & $\begin{array}{c}\text { Seats - } \\
\text { Power }\end{array}$ & $\begin{array}{c}\mid \text { Power- } \\
\text { Seats }\end{array}$ \\
\hline Finland & SFP & 0,171 & $-0,171$ & 0,171 \\
\hline Iceland & SDA & $-0,126$ & 0,126 & 0,126 \\
\hline Norway & Ap & 0,12 & $-0,12$ & 0,12 \\
\hline Iceland & Left-Green & $-0,106$ & 0,106 & 0,106 \\
\hline Norway & H & $-0,102$ & 0,102 & 0,102 \\
\hline Finland & VAS & $-0,084$ & 0,084 & 0,084 \\
\hline Sweden & S & 0,083 & $-0,083$ & 0,083 \\
\hline Denmark & RV & 0,082 & $-0,082$ & 0,082 \\
\hline Finland & SAML & $-0,078$ & 0,078 & 0,078 \\
\hline Iceland & SD & 0,078 & $-0,078$ & 0,078 \\
\hline Sweden & m & $-0,072$ & 0,072 & 0,072 \\
\hline Finland & GRÖNA & 0,072 & $-0,072$ & 0,072 \\
\hline Iceland & PA & $-0,064$ & 0,064 & 0,064 \\
\hline Denmark & V & $-0,064$ & 0,064 & 0,064 \\
\hline Iceland & WA & $-0,063$ & 0,063 & 0,063 \\
\hline
\end{tabular}




\begin{tabular}{l|c|c|c|c}
\hline Country & Party & $\begin{array}{c}\text { Power }- \\
\text { Seats }\end{array}$ & $\begin{array}{c}\text { Seats - } \\
\text { Power }\end{array}$ & $\begin{array}{c}\mid \text { Power- } \\
\text { Seats }\end{array}$ \\
\hline Iceland & LP & $-0,053$ & 0,053 & 0,053 \\
\hline Finland & SDP & $-0,048$ & 0,048 & 0,048 \\
\hline Denmark & S & $-0,048$ & 0,048 & 0,048 \\
\hline Finland & ASSF & 0,048 & $-0,048$ & 0,048 \\
\hline Sweden & nyd & 0,041 & $-0,041$ & 0,041 \\
\hline Iceland & PP & 0,039 & $-0,039$ & 0,039 \\
\hline Sverige & fp & $-0,038$ & 0,038 & 0,038 \\
\hline Finland & LIB & 0,034 & $-0,034$ & 0,034 \\
\hline Finland & CENT & $-0,03$ & 0,03 & 0,03 \\
\hline Denmark & DF & 0,03 & $-0,03$ & 0,03 \\
\hline Iceland & IP & 0,029 & $-0,029$ & 0,029 \\
\hline Denmark & CD & 0,026 & $-0,026$ & 0,026 \\
\hline Denmark & KF & $-0,024$ & 0,024 & 0,024 \\
\hline Norway & SV & 0,02 & $-0,02$ & 0,02 \\
\hline Sweden & kd & 0,018 & $-0,018$ & 0,018 \\
\hline Denmark & DR & 0,016 & $-0,016$ & 0,016 \\
\hline Norway & FrP & $-0,014$ & 0,014 & 0,014 \\
\hline Norway & V & $-0,013$ & 0,013 & 0,013 \\
\hline Sweden & mp & $-0,012$ & 0,012 & 0,012 \\
\hline
\end{tabular}

Note: SFP = Swedish Finns; SDA = Social Democratic Alliance (former SD); Ap = Norwegian social democrats; Left-Green = Icelandic environmentalists; $\mathrm{H}=$ Norwegian conservatives; VAS $=$ Finnish communists or left-socialists; $\mathrm{s}=$ Swedish social democrats; $\mathrm{RV}=$ Danish liberal radicals; $\mathrm{SAML}=$ Finnish conservaties; $\mathrm{SD}=$ Icelandic social democrats; $\mathrm{m}=$ Swedish conservatives; $\mathrm{PA}=$ Icelandic communistes or left-socialists ; V = Danish liberals; WA = Women Party; LP = Icelandic liberals ; SDP $=$ Finnish Social Democrats; $S=$ Danish Social Democrats; ASSF $=$ Finnish Left-Socialists ; nyd $=$ Swedish nationalists; $\mathrm{PP}=$ Icelandic Liberals $; \mathrm{fp}=$ Swedish liberals; $\mathrm{LIB}=$ Finnish liberals; CENT $=$ Finnish agrarians; $\mathrm{DF}=$ Danish nationalists; $\mathrm{IP}=$ Icelandic conservatives $; \mathrm{CD}=$ Danish centrists; $\mathrm{KF}=$ Danish conservatives; $\mathrm{SV}=$ Norwegian socialists; $\mathrm{kd}=$ Swedish christians; $\mathrm{DR}=$ Justice Party; $\mathrm{FrP}=$ Norwegian nationalists; $\mathrm{V}=$ Norwegian liberals $; \mathrm{mp}=$ Swedish environmentalists. All the numbers above are based upon normalised Banzhaf scores.

Table 2 presents with numbers several basic features in the political evolution of Nordic countries after the Second World War, as average power differentials of about 5-10 per cent - plus or minus - indicate political dominance or political powerlessness. It includes:

- Hegemony: Social Democracy in Norway (+ 12 per cent) and Sweden (+ 8 per cent). In Denmark and Finland, the Social Democrats have negative numbers when comparing percentage of mandates with Banzhaf normalised power scores, but for different reasons. The Danish Social Democrats never reached such a dominant position for the Arbeiterbewegung, as they faced 
fierce competition not only from non-socialist parties but also from the strong Left-Socialists, who early abandoned Communism. In Finland, the Communists could challenge the Social Democrats for a considerable part of the vote of the working classes, receiving about as many seats for a long time; yet, both the Social Democrats and the Left-Socialists (Communists) did not reach political power corresponding to their political representation. In Iceland, we also find social democratic hegemony up to 1990 as well as deficit for the Left-Socialists or Communists. Only in Norway has the Arbeiterbewegung maintained its political upper hand, whereas in Sweden the dominant position of the SAP with the national trade union LO crumbled, once the so-called bourgeois parties joined forces in stead of quarreling.

- Consociationalism: The Swedish Party in Finland has the highest power dispartity: + 17 per cent, because it is most often entered into the government coalition, although its support would not aleays be vital to the survival of the government;

- Pivot party: The classical small party in the political centre of the party system is the Danish Radicals, scoring an excess of 8 per cent;

- Losers: Given large party systems deviations from strict proportionality (power/seats), some parties have underperformed rather badly: the Norwegian and Finnish Conservatives, Greens in Iceland and Sweden as well as the Communists or Left-Socialists in Finland and Iceland. Paradoxically, the Danish Ventre has partcipated in several governments, but it has not achieved a power score that corresponds to its strong representation in the Folketing (- 6 per cent). Today, the Norwegian nationalists (FrP) face a large deficit.

One may speculate whether time promotes equal power for political parties in a democracy, given their shares of the electorate and corresponding seats in the national assembly. Probably this is not the case, except for minority government parliamentarism. Parties come and go. Only some of them score at or above strict proportionality.

A political party under a democratic regime with strong parliamentarism could be looked upon as a coalition of individuals - the principle of methodological individualism. This atomistic perspective on political parties is highly relevant when the national assembly is analysed, especially the voting behaviour in the national assembly.

\section{The Present Situation: Power of Individual Parliamentarians}

Looking next at political parties as mere coalitions among parliamentarians with a common program - the internal coalition -, we ask how much power the indi- 
vidual parliamentarians can achieve. It depends not only upon the internal coalition - the party - but also upon how their parties may enter in a government coalition - the external coalition. We must, logically speaking, separate between two situations involved in party government, the ex ante and the ex post government formation stage in Parliament. We illustrate these two stages for the parliamentarians in the present Nordic assemblies, suggesting a new and refined method for calculation the power of parliamentarians - Banzhaf numbers.

When the parliamentarians come to the national assembly after the election results are known and transformed into seats, they could from a logical point of view - theoretically speaking - vote as they like. Disregarding party loyalty completely, the single parlamentarian can achieve the following voting power by joining any coalition - Table 3 .

Table 3: Individual Member Parliamentary Power without Party Discipline (Non-normalised and normalised Banzhaf)

\begin{tabular}{l|c|c}
\hline Parliament & Banzhaf & Normalized Banzhaf \\
\hline Icelandic Althing & 0.10092 & 0.01587 \\
\hline Norwegian Storting & 0.06147 & 0.00592 \\
\hline Danish Folketing & 0.05972 & 0.00559 \\
\hline Finnish Eduskunta & 0.05635 & 0.00500 \\
\hline Swedish Riksdag & 0.04274 & 0.00287 \\
\hline
\end{tabular}

Note: Non-normalised Banzhaf numbers measure the probability of being decisive.

The differences in individual voting power in Table 3 reflect the size of the assembly. Thus, a member of Althing can exercise 0.02 per cent of the total voting power of that assembly, while a member of Swedish Riksdag only achieves 0.003 per cent of total voting power. Given these small power scores, it is to be expected that the parliamentarians start making coalitions in order to enhance their prospects. The parliamentarins would be most interested in increasing their probabilities of being decisive, for instance a low 0.06 probability in the Storting, Folketing or Eduskunta, whereas parliamentarians face a probability of being decisive of 0.10 in the Althing and 0.04 in the Riksdag. How could the individual voting power of parliamentarians be increased? Reply: By means of the making of coalitions: whether long-term ones creating parties or short-term ones, resulting in governments or ad hoc ones, as with voting on the many thousands of proposals that come up every year in the national assembly. 
Parliamentarians make - logically speaking - two different kinds of coalitions, both analysable with the power index approach:

- They gather together in a group called "party", deciding to coordinate their votes in Parliament (1).

- These so formed groups - party 1 , party 2 , party $\mathrm{N}$ - enter into a further stage of coalition formation, resulting in a government of some sort, minority, majority or grand coalitions (2).

One may now calculate individual power scores and compare the ex ante situation (1) with the two ex post situation (2). Rationality from an individual point of view implies that power scores go up for the parliamentarians who first form stable groups or political parties and second are successful in creating a governmental coalition - the principle of superadditivity for coalitions.

The voting power of an individual parlamentarian will be calculated below in a novel fashion, using three steps with non-normalised Banzhaf scores. First, the overall Banzhaf score of his//her party is derived. Second, the internal party Banzhaf scores will be calculated for each parliamentarian. Finally, the overall individual score for a parliamentarian is derived by multiplying his/her party score with the internal power score. How much can individual parliamentarians increase their voting power scores by engaging in coalition building from party groups to governments?

\section{Folketinget}

Table 4 has the following structure: the individual power scores for Danish parliamentarians before government formation (ex ante) are stated in the upper part of the Table, whereas the power scores of parliamentarians after (ex post) the establishment of a minority coalition government are contained in the lower part of the Table.

Table 4: Danish Folketing: Banzhaf power distribution

\begin{tabular}{l|c|c|c|c}
\hline Party & Seats & $\begin{array}{c}\text { Within } \\
\text { Party } \\
\text { Power }\end{array}$ & $\begin{array}{c}\text { Overall } \\
\text { Party/Gov } \\
\text { Power }\end{array}$ & $\begin{array}{c}\text { Individ- } \\
\text { ual Power }\end{array}$ \\
\hline S & 44 & 0.11960 & 0.47363 & 0.05665 \\
\hline RV & 17 & 0.19638 & 0.18262 & 0.03586 \\
\hline SF & 16 & 0.19638 & 0.18066 & 0.03548 \\
\hline KF & 8 & 0.27344 & 0.08887 & 0.02430 \\
\hline
\end{tabular}




\begin{tabular}{|c|c|c|c|c|}
\hline Party & Seats & $\begin{array}{l}\text { Within } \\
\text { Party } \\
\text { Power }\end{array}$ & $\begin{array}{c}\text { Overall } \\
\text { Party/Gov } \\
\text { Power }\end{array}$ & $\begin{array}{l}\text { Individ- } \\
\text { ual Power }\end{array}$ \\
\hline DF & 22 & 0.16819 & 0.25684 & 0.04320 \\
\hline $\mathrm{V}$ & 47 & 0.11700 & 0.52637 & 0.06159 \\
\hline EL & 12 & 0.22559 & 0.12793 & 0.02886 \\
\hline LA & 9 & 0.27344 & 0.09863 & 0.02697 \\
\hline Sambandspartiet & 1 & 1.00000 & 0.00684 & 0.00684 \\
\hline Socialdemokratiet & 1 & 1.00000 & 0.00684 & 0.00684 \\
\hline Siumut & 1 & 1.00000 & 0.00684 & 0.00684 \\
\hline Inuit Ataqatigiit & 1 & 1.00000 & 0.00684 & 0.00684 \\
\hline $\begin{array}{l}\text { Helle Thorning- } \\
\text { Schmidt }\end{array}$ & 77 & 0.09122 & 0.81250 & 0.07412 \\
\hline $\mathrm{KF}$ & 8 & 0.27344 & 0.06250 & 0.01709 \\
\hline $\mathrm{DF}$ & 22 & 0.16819 & 0.18750 & 0.03154 \\
\hline $\mathrm{V}$ & 47 & 0.11700 & 0.18750 & 0.02194 \\
\hline EL & 12 & 0.22559 & 0.17969 & 0.04053 \\
\hline LA & 9 & 0.27344 & 0.07031 & 0.01923 \\
\hline Sambandspartiet & 1 & 1.00000 & 0.00781 & 0.00781 \\
\hline Socialdemokratiet & 1 & 1.00000 & 0.00781 & 0.00781 \\
\hline Siumut & 1 & 1.00000 & 0.00781 & 0.00781 \\
\hline Inuit Ataqatigiit & 1 & 1.00000 & 0.00781 & 0.00781 \\
\hline
\end{tabular}

Note: All the numbers above are non-normalised Banzhaf power scores.

The finding is that parliamentarians increase their percentages of power from the above base line of 0.05972 (Table 1) by two kinds of coordination: first coordinating voting behaviour through the party group and, second, an additional coalition, namely the government, albeit it is not a simple majoritarian one. In the Folketing, the increase in voting power ex post for the parliamentarians supporting the government parties is clear (0.07412).

\section{Eduskunta and Stortinget}

When we come to the present situation in Finland and Norway, we deal with a simple majority government coalition, which entails an entirely different structure of the derived Banzhaf scores - see Table 5 and 6. 
Table 5: Finnish Eduskunta: Banzhaf power distribution

\begin{tabular}{l|r|c|c|c}
\hline Party & Seats & $\begin{array}{c}\text { Within } \\
\text { Party } \\
\text { Power }\end{array}$ & $\begin{array}{c}\text { Overall } \\
\text { Party/Gov } \\
\text { Power }\end{array}$ & $\begin{array}{c}\text { Individual } \\
\text { Power }\end{array}$ \\
\hline SAML & 44 & 0.11960 & 0.44141 & 0.05279 \\
\hline SDP & 42 & 0.12239 & 0.42578 & 0.05211 \\
\hline VF & 14 & 0.20947 & 0.21484 & 0.04500 \\
\hline GRÖNA & 10 & 0.24609 & 0.12891 & 0.03172 \\
\hline SFP & 9 & 0.27344 & 0.12109 & 0.03311 \\
\hline KD & 6 & 0.31250 & 0.07422 & 0.02319 \\
\hline CENT & 35 & 0.13583 & 0.28516 & 0.03873 \\
\hline SAF & 39 & 0.12859 & 0.34766 & 0.04470 \\
\hline ÅS & 1 & 1.00000 & 0.01172 & 0.01172 \\
\hline Jyrki Katainen & 125 & 0.07151 & 1.00000 & 0.07151 \\
\hline CENT & 35 & 0.13583 & 0.00000 & 0.00000 \\
\hline SAF & 39 & 0.12859 & 0.00000 & 0.00000 \\
\hline ÅS & 1 & 1.00000 & 0.00000 & 0.00000 \\
\hline
\end{tabular}

Table 6: Norwegian Storting: Banzhaf power distribution

\begin{tabular}{l|c|c|c|c}
\hline Party & Seats & $\begin{array}{c}\text { Within } \\
\text { Party } \\
\text { Power }\end{array}$ & $\begin{array}{c}\text { Overall } \\
\text { Party/Gov } \\
\text { Power }\end{array}$ & $\begin{array}{c}\text { Individual } \\
\text { Power }\end{array}$ \\
\hline $\mathrm{Ap}$ & 64 & 0.09935 & 0.75000 & 0.07451 \\
\hline $\mathrm{Sp}$ & 11 & 0.24609 & 0.12500 & 0.03076 \\
\hline $\mathrm{SV}$ & 11 & 0.24609 & 0.12500 & 0.03076 \\
\hline $\mathrm{H}$ & 30 & 0.14446 & 0.25000 & 0.03612 \\
\hline $\mathrm{KrF}$ & 10 & 0.24609 & 0.12500 & 0.03076 \\
\hline $\mathrm{FrP}$ & 41 & 0.12537 & 0.25000 & 0.03134 \\
\hline Jens Stoltenberg II & 86 & 0.08579 & 1.00000 & 0.08579 \\
\hline $\mathrm{H}$ & 30 & 0.14446 & 0.00000 & 0.00000 \\
\hline $\mathrm{V}$ & 2 & 0.50000 & 0.00000 & 0.00000 \\
\hline $\mathrm{KrF}$ & 10 & 0.24609 & 0.00000 & 0.00000 \\
\hline FrP & 41 & 0.12537 & 0.00000 & 0.00000 \\
\hline
\end{tabular}

Note: All the numbers above are non-normalised Banzhaf power scores. 
Yet, it holds for both the Finnish and Norwegian Parliament that individual parlamentarians increase their power ex post by entering into a party group that in turn becomes part of a government coalition. The parliamentarians supporting in addition the simple majority coalition government make voting power augmentations from 0.05635 to 0.07151 (Finland) and from 0.06147 to 0.08579 (Norway), comparing Tables 5 and 6 with Table 1.

\section{Riksdagen}

When we come to the Swedish situation, then we have again a minority coalition governing the country, meaning that parliamentarians outside of the ruling coalition score Banzhaf points - see Table 7.

Table 7: Swedish Riksdag: Banzhaf power distribution

\begin{tabular}{l|r|r|c|c}
\hline Party & Seats & $\begin{array}{c}\text { Within } \\
\text { Party } \\
\text { Power }\end{array}$ & $\begin{array}{c}\text { Overall } \\
\text { Party/Gov } \\
\text { Power }\end{array}$ & $\begin{array}{c}\text { Individual } \\
\text { Power }\end{array}$ \\
\hline $\mathrm{m}$ & 107 & 0.07731 & 0.42188 & 0.03262 \\
\hline $\mathrm{c}$ & 23 & 0.16819 & 0.14062 & 0.02365 \\
\hline $\mathrm{fp}$ & 24 & 0.16118 & 0.20312 & 0.03274 \\
\hline $\mathrm{kd}$ & 19 & 0.18547 & 0.10938 & 0.02029 \\
\hline $\mathrm{mp}$ & 25 & 0.16118 & 0.23438 & 0.03778 \\
\hline $\mathrm{s}$ & 112 & 0.07522 & 0.57812 & 0.04349 \\
\hline $\mathrm{v}$ & 19 & 0.18547 & 0.10938 & 0.02029 \\
\hline $\mathrm{sd}$ & 20 & 0.17620 & 0.14062 & 0.02478 \\
\hline Fredrik Reinfeldt $\mathrm{II}$ & 173 & 0.06075 & 0.87500 & 0.05316 \\
\hline $\mathrm{mp}$ & 25 & 0.16118 & 0.12500 & 0.02015 \\
\hline $\mathrm{s}$ & 112 & 0.07522 & 0.12500 & 0.00940 \\
\hline $\mathrm{v}$ & 19 & 0.18547 & 0.12500 & 0.02318 \\
\hline $\mathrm{sd}$ & 20 & 0.17620 & 0.12500 & 0.02202 \\
\hline $\mathrm{N}$ & &
\end{tabular}

Note: All the numbers above are non-normalised Banzhaf power scores.

The increase in voting power for the parliamentarians backing the minority government is obvious - up to 0.05316 , to be compared with the baseline scores above of 0.04274 with voting without party discipline (Table 1). Ex post parliamentarians increase their voting power by entering party groups and creating a government coalition with individual voting power. 


\section{Althing}

The Icelandic situation (Table 8) adheres to the logic of a majority coalition government.

Table 8: Icelandic Althing: Banzhaf power distribution

\begin{tabular}{l|r|c|c|c}
\hline Party & Seats & $\begin{array}{c}\text { Within } \\
\text { Party } \\
\text { Power }\end{array}$ & $\begin{array}{c}\text { Overall } \\
\text { Party/Gov } \\
\text { Power }\end{array}$ & $\begin{array}{c}\text { Individual } \\
\text { Power }\end{array}$ \\
\hline SDA & 20 & 0.17620 & 0.62500 & 0.11012 \\
\hline Left-Green & 14 & 0.20947 & 0.37500 & 0.07855 \\
\hline PP & 9 & 0.27344 & 0.12500 & 0.03418 \\
\hline IP & 16 & 0.19638 & 0.37500 & 0.07364 \\
\hline Other & 4 & 0.37500 & 0.12500 & 0.04688 \\
\hline Jóhanna & 34 & 0.13583 & 1.00000 & 0.13583 \\
\hline Pigurðardóttir & 9 & 0.27344 & 0.00000 & 0.00000 \\
\hline IP & 16 & 0.19638 & 0.00000 & 0.00000 \\
\hline Other & 4 & 0.37500 & 0.00000 & 0.00000 \\
\hline
\end{tabular}

Note: All the numbers above are non-normalised Banzhaf power scores.

Here, only the parliamentarians in the ruling coalition score more voting power ex post - up to a probability of 0.14 from 0.10 (Table 1). However, ex ante superadditivity holds for one party, the SDA, as their parliamentarians score better than the baseline points in a randomly structured national assembly. The same superadditivity ex ante - applies to one other party, namely the Norwegian AP.

\section{Conclusion}

Members of the national assembly tend to have a complex objective function, including both self-centred and collective goals, both mundane and idealistic aims. The capacity of parliamentarians to realize their objectives, whatever they may be, depend upon coalition behaviour in Parliament, first the internal coalition resulting in the party, and second the external coalition, from which the government coalition emerges. Democracy under party government in a party system with multi-partism and a high extent of party discipline is based upon the Stresemann latchkey to power, i.e. coalition making and unmaking endlessly, well capturaed with the tools of cooperative game theory, such as the so-called Penrose-Banzhaf-Coleman approach. 


\section{Appendix}

The Banzhaf voting power index models the marginal contribution of a player to the success of a coalition, given a social choice mechanism. ${ }^{3}$ Looking here at the so-called Penrose-Banzhaf framework for solving $\mathrm{N}$-person games, one starts from the characteristic function of a game by considering the set $2^{n}$ of all possible employing the assumption of equally likely coalitions. From these $2^{n}$ coalitions the Banzhaf score of player $i$ is calculated as the number of coalitions in which i is critical, that is, the number of coalitions that player $i$ is able to swing. The Penrose-Banzhaf power index of player $\beta i$ is defined by the ratio of swings $\eta$ to coalitions. Thus, we have

$$
\beta_{i}=\frac{\eta_{i}}{2^{n-1}}
$$

Inserting the so-called characteristic form of the game in question, we get:

$$
\beta_{i}=\frac{\eta_{i}}{2^{n-1}} \sum_{\substack{S \subseteq N \\ i \in S}}[v(S)-v(S \backslash\{i\})]
$$

The group capacity of arriving at a decision is the total winning coalitions of the game, $d=\left|W_{(N, v)}\right|$, which is obtained by:

$d=\sum_{S \subseteq N} v(S)$

Relating this group capacity to the total number of possible coalitions of a game we obtain $\delta$, the probability of decisiveness of a game,

$\delta=\frac{d}{2^{n}}$.

3 Banzhaf, J.F. III: Weighted Voting Doesn't Work: A Mathematical Analysis, in: Rutgers Law Review 19 (1965), 317-343; Coleman, J.S.: Control of Collectivities and the Power of a Collectivity to Act, in Lieberman, B. (ed.): Social Choice, New York, 1971, 269-300, reprinted in Coleman, J.S.: Individual Interests and Collective Action, Cambridge, 1986; Felsenthal, D./Machover, M.: The Measurement of Voting Power, Cheltenham, 1998; Felsenthal, D.S./Machover, M.: Annexations and Alliances: When Are Blocs Advantageous A Priori?, in: Social Choice and Welfare 19, (2002), 295-312; Felsenthal, D.S./Machover, M.: A Priori Voting Power: What Is It All About?, in: Political Studies Review, 2, (2004), 1-23; Felsenthal, D.S./Machover, M.: Voting Power Measurement: A Story of Misreinvention, in: Social Choice and Welfare, 25 (2-3) (2004), 485-506; Owen, G.: Game Theory, San Diego, 1995; Riker, W.H./Ordeshook, P.C.: An Introduction to Positive Political Theory, New York, 1973. 
This parameter $\delta$ is much employed in order to understand the differences between the three basic voting schemes of a group: simple majority (SM), qualified majority (QM) and unanimity (veto). The number of individual swings, $\eta_{\mathrm{i}}$ is another crucial parameter derived in this index. This parameter $\eta$ measures the number of swings a player can make, either swinging from "yes" to "no" or from "no" to "yes", thereby altering the group outcome. The Penrose-Banzhaf index relates this parameter $\eta$ to the total number of winning coalitions, $d$, in order to obtain the individual probability of blocking of a player $i$. Thus, we arrive at another basic parameter $\theta$ :

$$
\theta_{i}=\frac{\eta_{i}}{d}
$$

Advanced game theory has proved that the Penrose-Banzhaf overall power index parameter $\beta$ can be factorised into the product of the probability of decisiveness, $\delta$, twice the individual probability of blocking, $\theta$. Thus, we have:

$$
\beta_{i}=2 \delta \theta_{i}
$$

The doubling of the individual probability of blocking reflects the fact that the Banzhaf index is based on the two basic symmetric capabilities to swing a game, from "yes" to "no" as well as from "no" to "yes". One arrives thus at the following general definition of the Penrose-Banzhaf power index: Penrose-Banzhaf power amounts to twice the product of the probability of decisiveness, $\delta$, and the individual probability of blocking $\theta_{\mathrm{i}}$. 